\title{
Animacy, definiteness, and case in Cappadocian and other Asia Minor Greek dialects* $^{*}$
}

\author{
Mark Janse \\ Ghent University and Roosevelt Academy, Middelburg
}

This article discusses the relation between animacy, definiteness and case in Cappadocian and several other Asia Minor Greek dialects. Animacy plays a decisive role in the assignment of Greek and Turkish nouns to the various Cappadocian noun classes. The development of morphological definiteness is due to Turkish interference. Both features are important for the phenomenon of differential object marking which may be considered one of the most distinctive features of Cappadocian among the Greek dialects.

Keywords: Asia Minor Greek dialectology, Cappadocian, Farasiot, Lycaonian, Pontic, animacy, definiteness, case, differential object marking, Greek-Turkish language contact, case typology

\section{Introduction}

It is well known that there is a crosslinguistic correlation between case marking and animacy and/or definiteness (e.g. Comrie 1989: 128ff., Croft 2003: 166ff., Linguist List 9.1653 \& 9.1726). In nominative-accusative languages, for instance, there is a strong tendency for subjects of active, transitive clauses to be more animate and more definite than objects (for Greek see Lascaratou 1994: 89). Both animacy and definiteness are scalar concepts. As I am not concerned in this article with pronouns and proper names, the person and referentiality hierarchies are not taken into account (Croft 2003: 130): ${ }^{1}$

(1) a. animacy hierarchy

human $<$ animate $<$ inanimate

b. definiteness hierarchy

definite $<$ specific $<$ nonspecific 
With regard to case marking, there is a strong tendency to mark objects that are high in animacy and/or definiteness and, conversely, not to mark objects that are low in animacy and/or definiteness. This tendency is referred to as 'differential object marking' (DOM) by Aissen (2003), after Bossong (1985). Russian first-declension masculine nouns, for instance, have a separate accusative (formally identical with the genitive) only if they are animate (Comrie 1987: 339): ${ }^{2}$

(2) a. stáryj slon

old.NOM.sG elephant.NOM.SG

stárogo sloná

old.ACC/GEN.SG elephant.ACC/GEN.SG

b. stárye sloný

old.NOM.PL elephant.NOM.PL

stáryx slonóv

old.ACC/GEN.PL elephant.ACC/GEN.PL

(3) a. stáryj stol

old.NOM/ACC.sG table.NOM/ACC.sG

b. stárye stolý

old.NOM/ACC.PL table.NOM/ACC.PL

Turkish nouns take the accusative suffix - $(y) I$ only if they are definite or specific (Kornfilt 1997: 214), as in the following examples (note that definite objects obligatorily precede indefinite (specific or nonspecific) objects):

(4) a. öykü-yü bir çocuğ-a anlat-tı

story-ACC a child-DAT tell-PAST.3sG

"s/he told the story to a child"

b. çocuğ-a bir öykü-yü anlat-tı

child-DAT a story-ACC tell-PAST.3SG

"s/he told the child a (specific) story"

c. çocuğ-a bir öykü-Ø anlat-tı

child-DAT a story-ABs tell-PAST.3sG

"s/he told the child a (nonspecific) story"

Greek resorts to articles to mark the difference between definite and indefinite nouns and noun phrases. The indefinite article may be omitted when the noun phrase is non-specific (Holton et al. 1997: 284): ${ }^{3}$

(5) a. ipe tin istoría séna peðí

tell.AOR.3sg the story to.a child

"s/he told the story to a child" 


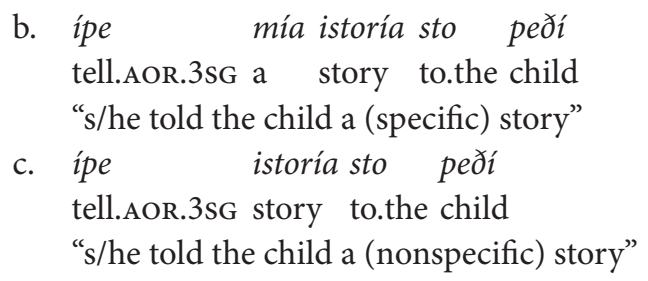

As can be seen in the preceding examples, the Greek gender classes do not necessarily correspond to the division between male, female, and inanimate (see Anastasiadi-Symeonidi et al. 2003): istoría is a feminine noun but refers to an inanimate (abstract) being, and peðí is a neuter noun but refers to an animate (human) being. Nevertheless, only masculine and feminine nouns (whatever their original natural or perceived relation, if any, to male and female animate beings) exhibit differential object marking and the same applies to the masculine and feminine articles, both definite and indefinite.

Among many other things, Cappadocian is remarkable among the Greek dialects for its highly original noun declension. In North and Central Cappadocian, noun classes are largely based on considerations of animacy, which especially affect the declension of the ancient masculine nouns in -os and play an essential part in the assignment of Turkish loans to inflectional classes. ${ }^{4}$ The originally masculine $o$-stems are split into two classes: animate nouns which take the masculine article except in the nominative, and inanimate nouns which take the neuter article in all cases. The plural of both classes is characterized by a certain degree of syncretism and reanalysis, which varies across subdialects. In Northwest Cappadocian and at Mistí (Central Cappadocian), animate nouns have a syncretic plural ending $-i$ or $-\varnothing<-i$, which is the ancient ending of the masculine nominative plural. In Northwest and Northeast Cappadocian, inanimate nouns have the syncretic plural ending -us or -us, which is the ancient ending of the masculine accusative plural. At Axó (Central Cappadocian), inanimate nouns have an agglutinative syncretic plural ending -ja which is taken from the ancient neuter nouns in $-i$.

In both North and Central Cappadocian, animate and inanimate $o$-stems have the separate accusative singular ending - $o$ only if they are definite. Like the Turkish absolutive in (4c), the indefinite accusative is formally identical with the nominative. The conflation of nominative and indefinite accusative singular has resulted in the reanalysis of both cases in several subdialects. In Northwest Cappadocian, for instance, there is evidence of an emerging definiteness-split in the declension of inanimate nouns: indefinite nominative/accusative singular in -os vs. definite nominative/accusative singular in -o. In Central 
Cappadocian, on the other hand, there is a clear tendency towards syncretism in the declension of inanimate nouns: nominative/accusative singular in -os, whether indefinite or not. The conflation and ultimately confusion of nominative and accusative singular may have paved the way for the generalization of the agglutinative declension in Southern Cappadocian, where both animate and inanimate nouns have become formally neuter.

In this article I take a closer look at the relation between animacy, definiteness and differential object marking and its manifold manifestations in Cappadocian. Section 2 gives a partial sketch of Cappadocian noun declension and the relation between noun classes and animacy. Section 3 discusses the relation between animacy, definiteness, differential object marking, and the use of the definite article and possessive suffixes in Cappadocian (with notes on the neighbouring dialects, Farasiot and Lycaonian). Section 4 presents examples of differential object marking in Cappadocion. An appendix ends the article with a note on differential subject marking in Pontic.

\section{Cappadocian noun declension}

\subsection{Neuter nouns in $-i>-\varnothing$}

Neuter nouns in $-i>-\varnothing$ take up a central position in Cappadocian. ${ }^{5}$ It is by far the largest noun class, including inanimates such as Oir "door", animates such as vó $\theta$ "ox", and humans such as korítš "girl". The originally diminutive meaning has disappeared and is expressed by suffixes such as -oppo (Janse 2004: $\$ 5.3 .1 .3$ ), e.g. koritšóppo. ${ }^{6}$ A hypocoristic meaning may be perceived in human and possibly also animate nouns in $-i>-\varnothing$. Their declension is as follows (Dawkins 1916: 90, Janse 2004: \$3.2.1.1):

(6)

\begin{tabular}{|c|c|c|}
\hline SG & PL & \multirow{3}{*}{$\begin{array}{l}\text { NOM-ACC } \\
\text { GEN }\end{array}$} \\
\hline mát- $\varnothing$ & mát-ja & \\
\hline mat-jú & & \\
\hline
\end{tabular}

Turkish inanimate nouns in -C are integrated in this class, e.g. gül "rose" > gül (note that there is no separate form for the genitive plural): ${ }^{7}$

\begin{tabular}{|c|c|c|}
\hline SG & PL & \\
\hline gül- $\varnothing$ & gülil-ja & NOM-ACC \\
\hline \multicolumn{2}{|c|}{ gül-jú (gül-jü $)^{8}$} & GEN \\
\hline
\end{tabular}


On the analogy of the Turkish agglutinative noun declension, neuters in $-i>-\varnothing$ have come to be reanalyzed as oxytone neuters in $-\mathrm{C}$ with three agglutinative case and number suffixes: nominative-accusative (absolutive) $-\varnothing$, genitive $-j u$ $(-j u)$, plural -ja. Compare the equivalent cases in the Turkish paradigm:

(8)

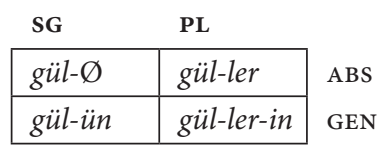

The case and number suffixes nominative-accusative (absolutive) - $\varnothing$, genitive $-j u ́(-j u)$, and plural -ja have been generalized and spread to other noun classes (cf. infra).

\subsection{Ancient masculine nouns in -os}

Ancient masculine nouns in -os are characterized by what could be called an animacy split: nouns referring to animates are treated as masculine nouns, whereas nouns referring to inanimates are treated as neuter nouns (Dawkins 1916: 93ff., Janse 2004: $\$ \$ 3.2 .1 .4,3.2 .2 .1)$. The distinction between aninates and inanimates is not always consistent: pšílos "flea" is considered an animate, hence masculine noun at Potámja (Northeast Cappadocian), but an inanimate, hence neuter noun at Mistí, whereas jéros "old man" is everywhere treated as an inanimate noun. The difference between animate and inanimate nouns in -os appears in the declension and the use of the definite article, which is used exclusively in the accusative (masculine-animate singular to $(n)$, plural tus, neuter-inanimate singular to, plural ta), except at Axó where it is also used in the genitive (singular-plural $t$ from generalized $t u$ ).

In Northeast Cappadocian and at Axó (Central Cappadocian) the declension of masculine-animate nouns in -os is as follows (átropos "man"):

(9) a.

\begin{tabular}{|c|c|c|}
\hline \multirow{5}{*}{$\begin{array}{r}\text { INDEF } \\
\text { DEF }\end{array}$} & SG & PL \\
\hline & áAropos & aөróp \\
\hline & áAropos & \multirow{2}{*}{$\begin{array}{l}\text { ärópus } \\
\text { ärop-jús }\end{array}$} \\
\hline & áAropo & \\
\hline & \multicolumn{2}{|l|}{$\begin{array}{l}\text { a } \operatorname{cróp} \\
\text { aөrop-jú }\end{array}$} \\
\hline
\end{tabular}

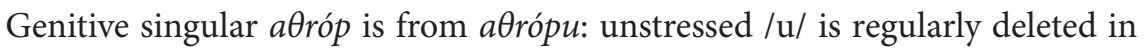
word-final position, just as unstressed /i/ (see n. 5), whence nominative plural 
a $\operatorname{cóp}$ from a $\operatorname{\theta rópi}$ (with penultimate stress!). Note, however, that the genitive singular has an agglutinative allomorph $-j u$, which is taken from the neuter nouns in $-i>-\varnothing$ (and which, incidentally, indicates that the stem was interpreted as ${ }^{\circ} a$ (rop-). On the analogy of this agglutinative genitive singular an agglutinative accusative plural in -jús was created which is generally used as a variant of the ancient accusative plural in - $u s$ in these subdialects, except at Axó where the agglutinative form is used exclusively: $\operatorname{arçop-jús.~}{ }^{9}$ Note that there is no separate form for the genitive plural, except at Axó where a remarkable agglutinative form is found: árçopoz-ju (genitive singular arçóp).

Very remarkable is the existence of two separate forms for the accusative singular: a definite accusative in $-o$ and an indefinite accusative in -os. The latter is, of course, formally identical with the nominative singular on the analogy of the Turkish absolutive, which is used to mark subjects and indefinite or, more accurately, nonspecific direct objects as in (4c). In Cappadocian the distinction between nonspecific and specific is not observed and the accusative in $-o s$ is used for indefinite direct objects generally. The presence of two different forms for the accusative singular sometimes leads to confusion. Thus one finds, e.g., definite nominatives in -o or syncretic nominative-accusatives in either -os or -o (cf. infra).

In Northwest Cappadocian and at Mistí (Central Cappadocian) there is no separate form for the accusative plural, which is formally identical with the nominative plural:

(9) b.

\begin{tabular}{|c|c|c|}
\hline \multirow{4}{*}{$\begin{array}{r}\text { INDEF } \\
\text { DEF }\end{array}$} & SG & PL \\
\hline & átropos & äróp \\
\hline & áAropos & \multirow{2}{*}{ äróp } \\
\hline & átropo & \\
\hline & \multicolumn{2}{|l|}{ aAróp } \\
\hline
\end{tabular}

In North Cappadocian the declension of neuter-inanimate nouns in -os differs in one important respect from the declension of the masculine-animate nouns: there is no separate form for the nominative plural, which is formally identical with the accusative plural (milos "mill"): 
(10) a.

\begin{tabular}{|c|c|c|}
\hline \multirow{4}{*}{$\begin{array}{r}\text { INDEF } \\
\text { DEF }\end{array}$} & SG & PL \\
\hline & mílos & mílus \\
\hline & mílos & \multirow[t]{2}{*}{ mílus } \\
\hline & mílo & \\
\hline & míl & \\
\hline
\end{tabular}

The difference can be explained only as a consequence of the animacy hierarchy: since subjects are generally more animate than objects, it was the nominative that was generalized in the case of the masculine-animate nouns and the accusative in the case of the neuter-inanimate nouns. The question of why there should be syncretism in the first place is often explained in terms of markedness: the plural being marked as opposed to the singular, there is a "tendency toward fewer subcategories of the plural" (Waugh \& Lafford 1994: 2379)..$^{10}$ The difference between the syncretic nominative-accusative plural of masculine-animate vs. neuter-inanimate nouns can also be explained in terms of markedness: the unmarked case for animate nouns is the nominative, whereas the unmarked case for inanimate nouns is the accusative. The generalization is thus based on the unmarked case in both instances. Note that syncretism of the nominativeaccusative plural is found in many Greek dialects (Thumb 1910: 42).

In Central Cappadocian the neuter-inanimate nouns in -os have an almost entirely agglutinative declension. The nominative singular is reanalyzed as a stem to which the agglutinative case and number suffixes, genitive $-j u(-j u)$ and plural - $j a$, are attached. The difference between definite and indefinite accusative is occasionally retained:

(10) b.

\begin{tabular}{|c|c|c|}
\hline & SG & PL \\
\hline \multirow{3}{*}{ INDEF } & mílos & míloz-ja \\
\hline & mílos & \multirow[t]{2}{*}{ míloz-ja } \\
\hline & mílo(s) & \\
\hline & \multicolumn{2}{|c|}{ míloz-ju } \\
\hline
\end{tabular}

In Southeast and Southwest Cappadocian, the distinction between animate and inanimate nouns has disappeared and all nouns have become formally neuter (and take the neuter article). The following paradigm is from Ulağáç (átropos "man"): 
(11)

\begin{tabular}{|c|c|}
\hline SG & PL \\
\hline átropos & átropoz-ja \\
\hline átropoz- & átropoz-ja-j \\
\hline
\end{tabular}

Very remarkable is the agglutinative genitive plural átropoz-ja-ju elicited from one of the last speakers from Ulağaç by Sasse (1992: 65): it is built exactly like the Turkish genitive plural gül-ler-in (8). ${ }^{11}$

2.3 Masculine nouns in -is etc. (parisyllabic) and -ís etc. (imparisyllabic)

In North, Central, and Southwest Cappadocian, except at Ferték, masculine nouns in -is etc. (parisyllabic) and -ís etc. (imparisyllabic) have the same characteristics as the masculine-animate nouns in -os (Dawkins 1916: 108ff., Janse 2004: \$3.2.2.2f.). They always refer to animates, distinguish between definite and indefinite accusative singular, and have agglutinative allomorphs in genitive singular and accusative plural and a syncretic nominative-accusative plural formally identical with the nominative if no separate accusative is distinguished, as in the following examples (kléftis "thief”, papás “priest"):

\begin{tabular}{|c|c|c|}
\hline & SG & PL \\
\hline \multirow{4}{*}{$\begin{array}{r}\text { INDEF } \\
\text { DEF }\end{array}$} & kléftis & kléftes \\
\hline & kléftis & kléftes \\
\hline & kléft & kleft-jús \\
\hline & $\begin{array}{l}\text { kléft } \\
\text { kleft-jú }\end{array}$ & \\
\hline
\end{tabular}

(13) a.

\begin{tabular}{|c|c|c|}
\hline \multirow{4}{*}{$\begin{array}{r}\text { INDEF } \\
\text { DEF }\end{array}$} & SG & PL \\
\hline & papás & рара́ðеs \\
\hline & papás & papáðes \\
\hline & papá & рараð-jús \\
\hline & \multicolumn{2}{|c|}{$\begin{array}{l}\text { рара́ } \\
\text { рараð-jú }\end{array}$} \\
\hline
\end{tabular}

At Axó, a separate genitive plural built on the Turkish model is found: kléftez-ju, papájez-ju (Mavrochalyvidis \& Kesisoglou 1960: 39). Turkish animate nouns in -C and -V are generally integrated in this class: padişah "king" > patišáxis or, with vowel harmony, patišáxïs (sometimes patišáxos); paşa “elder brother” > bašás. In Southeast Cappadocian and at Ferték these nouns follow the agglutinative declension. The following example is from Ferték (papás "priest”): 
(13) b.

\begin{tabular}{|l|l|l}
\multicolumn{1}{l}{ SG } & \multicolumn{2}{l}{ PL } \\
\cline { 1 - 2 } papás & papáz-ja & NOMCC \\
papaz-jú & $($ papáz-ja-ju $)$ & GEN
\end{tabular}

\subsection{Feminine nouns $-a$}

In North, Central, and Southwestern Cappadocian, feminine nouns in - $a$ have a syncretic nominative-accusative and (therefore?) no distinction between definite and indefinite accusative (Dawkins 1916: 113f., Janse 2004: \$3.2.3.1). The declension is the same as in Standard Modern Greek (néka "woman”):

(14) a.

\begin{tabular}{|l|l|l}
\multicolumn{1}{l}{ SG } & \multicolumn{2}{l}{ PL } \\
néka & nékes & GEN \\
\cline { 1 - 1 } nékas &
\end{tabular}

As was the case of the masculine-animate nouns in -os, the definite article is used exclusively in the accusative (singular ti(n), plural ta), except at Axó where it is also used in the genitive (singular-plural $t$ from generalized accusative singular $t i$ and on the analogy of masculine $t<t u$ ). In Southwest Cappadocian, as in Southeast Cappadocian, feminine nouns take the neuter article in the singular as well.

At Axó, a separate genitive plural is found which is the same as in Southeast Cappadocian, where almost the entire declension has become agglutinative with the exception of the nominative-accusative plural:

(14) b.

\begin{tabular}{|l|l|l|l}
\multicolumn{1}{l}{ SG } & \multicolumn{1}{l}{ PL } \\
\hline néka & nékes & \multirow{2}{*}{ NOM-ACC } \\
néka-ju & $n e ́ k e z-j u$ & GEN
\end{tabular}

2.5 Feminine nouns in $-i>-\varnothing$

In North, Central, and Southwestern Cappadocian, feminine nouns in $-i>$ - $\varnothing$ follow either the parisyllabic or the imparisyllabic declension (Dawkins 1916: 114f., Janse 2004: \$3.2.3.2). In neither case is there a distinction between definite or indefinite accusative. Remarkably, most subdialects have a separate genitive plural (nif "bride"): 
(15)

\begin{tabular}{|c|c|c|}
\hline SG & PL & \\
\hline nif & $\begin{array}{l}\text { nífes } \\
\text { nifádes }\end{array}$ & NOM-AC \\
\hline $\begin{array}{l}\text { nifis } \\
\text { nifað-jú }\end{array}$ & $\begin{array}{l}\text { nif-jú } \\
\text { nifáðez-ju }\end{array}$ & GEN \\
\hline
\end{tabular}

Since feminine nouns in $-i>-\varnothing$ look the same as neuter nouns in $-i>-\varnothing$, since both noun classes end in -C, it should come as no surprise that nouns referring to inanimates are often declined as neuter nouns. In Southeast Cappadocian all originally feminine nouns in $-i>-\varnothing$ are treated like this:

(15) b.

\begin{tabular}{|l|l|l}
\multicolumn{1}{l}{ SG } & \multicolumn{1}{l}{ PL } \\
\cline { 2 - 2 } nif & nif-ja & NOM-ACC \\
\cline { 2 - 2 } nif-jú & $($ nif-ja-ju $)$ & GEN \\
\hline
\end{tabular}

\section{Definiteness and differential object marking in Cappadocian}

3.1 Use, abuse, and disuse of the definite article

As already remarked, masculine-animate and feminine nouns never take the definite article in the nominative, except in South Cappadocian where all nouns have become formally neuter (Dawkins 1916: 87ff., Janse 2004: \$4.1.1.1). Neuter nouns, by contrast, take the article in both the nominative and the accusative. Consider the following examples from Sílata (Northwest Cappadocian):

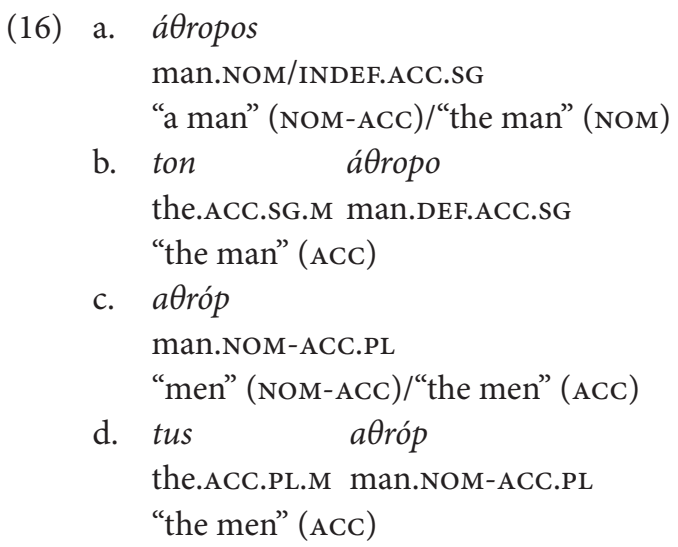


The reason, I believe, is that the nominative being formally identical with the indefinite accusative was considered incompatible with the definite article. The disuse of the masculine article in the singular must have been extended to the plural and from there to the feminine article (which was identical with the masculine article in the plural, both being $i$ ). The neuter article could be used in both the nominative and the accusative because of the syncretism of both cases, the only exception being neuter-inanimate nouns in -os which, as we have seen, tend to suppress the distinction between animate and inanimate accusative (cf. supra).

It may be useful to compare the Cappadocian situation with that of two neighbouring dialects. Lycaonian, the dialect of Sílli, has no indefinite accusative, but the definite article is nevertheless used in the accusative only (Dawkins 1916: 46), as in the following examples (ártupus "man”):
a. ártupus
man.NOM.SG
"a man" (NOM)/"the man" (NOM)
b. tun $\operatorname{artupu(n)}$
the.ACC.SG.M man.ACC.SG
"the man" (ACC)
c. ártupuri
man.NOM-ACC.PL
"men" (NOM)/"the men" (NOM)
d. tus ártupuri(s)
the.ACC.SG.M man.ACC.PL
"the men" (ACC)

Farasiot has an indefinite accusative singular formally identical with the nominative and a syncretic nominative-accusative plural formally identical with the nominative, but the definite article is used in the nominative as well as the accusative (Dawkins 1916: 163), as in the following examples (nomáts “man”):

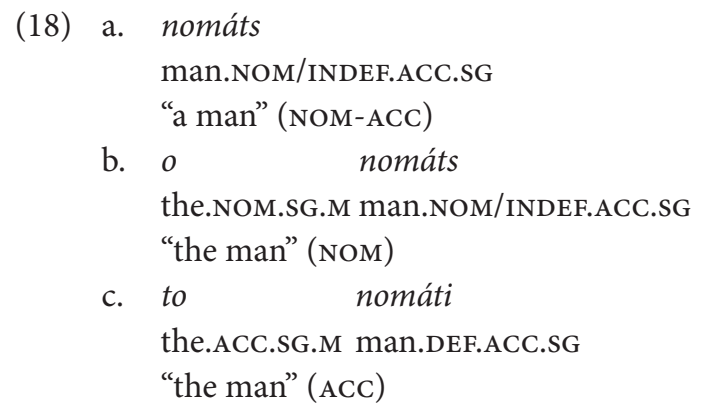




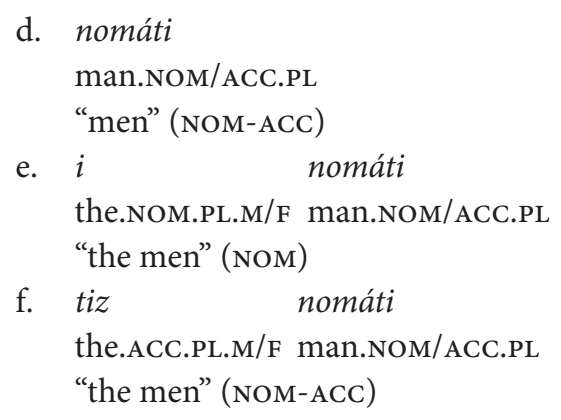

3.2 Reanalysis and the possessive suffixes

The syncretism in the nominative and indefinite accusative masculine-animate and partly also in neuter-inanimate nouns in North and Central Cappadocian has led to the reanalysis of $s$ as a suffix marking indefiniteness (more examples below):
a. éna
mílo-s
a.NOM-ACC.SG mill-INDEF.NOM/ACC
"a mill" (NOM-ACC)
b. to mílo
the.NOM-ACC.SG.N mill.DEF.NOM/ACC.SG
"the mill" (NOM-ACC)

The psychological reality of this interpretation is supported by the fact that indefinite $s$ is occasionally attached to words belonging to other noun classes (Dawkins 1916: 94, Janse 2004: \$3.2.1.4 n. 7), as in the following examples from Delmesó (Northeast Cappadocian):
(20) a. so
kujú $^{12}$
to.the.ACC.SG well.NOM/ACC.SG
"to the well"
b. séna kujú-s
to.a.ACC.SG well-INDEF.ACC.SG
"to a well"
(21) a. so peyát
to.the.ACC.sG spring.NOM/ACC.SG
"to the spring"
b. séna peyádi-s
to.a.ACC.SG spring-INDEF.ACC.SG
"to a spring" 
(22) a. so

xorjó

to.the.ACC.SG village.NOM/ACC.SG

"to the village"

b. séna xorjó-s

to.a.ACC.SG village-INDEF.ACC.SG

"to a village"

Further support may be found in the attachment of the possessive suffixes to the $s$-less stem of masculine-animate nouns in -os (Janse 2004: \$3.4.2.2, pace Dawkins 1916: 121f.). The presence of a possessive suffix suffices to make a noun definite, so the $s$ is dropped, as in to mílo in (19b). Compare the following examples from Axó (Central Cappadocian): ${ }^{13}$

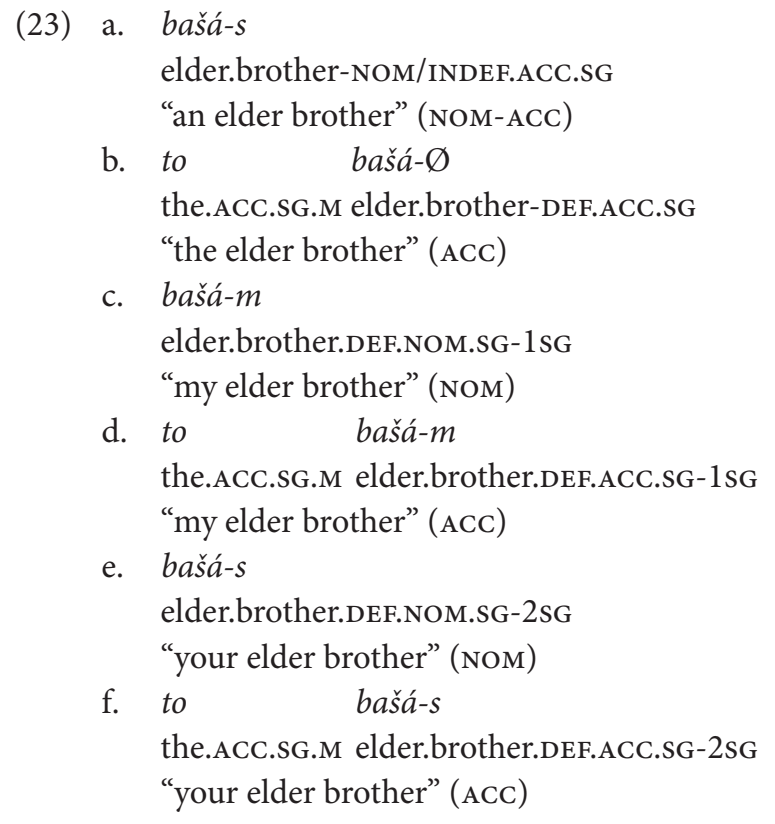

Neuter-inanimate nouns, on the other hand, seem to follow the Turkish pattern (Lewis 2000: 38), as in the following examples, again from Axó:

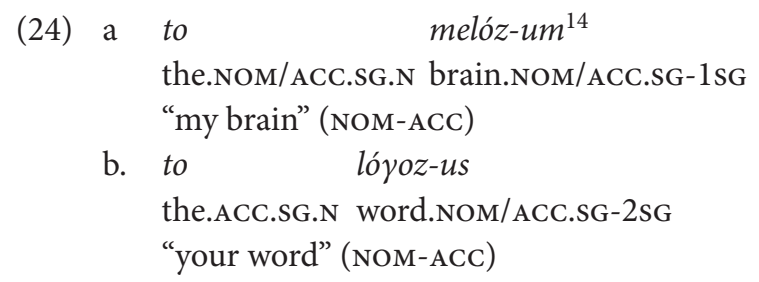



c. to vrómoz-ut
the.ACC.SG.N stench.NOM/ACC.SG-3SG
"its stench"

In South Cappadocian the Turkish pattern is generalized. Compare the Turkish (25a) and Cappadocian (25b) paradigms of kardaş "brother" > gardáš (Ulağáç):

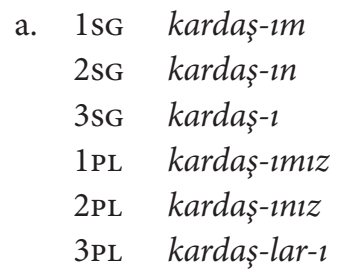
b. gardáš-ïm gardáš-ïs gardáš-ït gardáš-ïmas gardáš-ïsas gardáš-ïtne

\section{DOM in action}

In this section I present some evidence of Cappadocian differential object marking (DOM). It is important to realize that DOM is a tendency in Cappadocian. There are several competing factors such as the already mentioned tendency towards syncretism, not just in the plural but in the singular as well (illustrated in some of the examples). The evidence is practically confined to North, Central, and, to a limited extent, Southwest Cappadocian. Contextual information is supplied whenever this seemed useful.

The first set of examples is taken from a folktale from Flojitá (Northwest Cappadocian), featuring a magic boy and, in this particular scene, a boy and an unfortunate dervish (Dawkins 1916: 414):

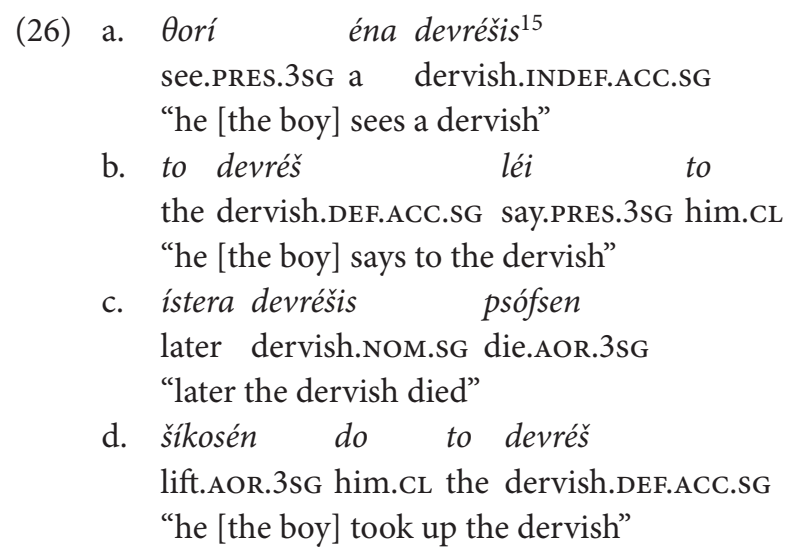


The difference between the indefinite accusative devrésis and the definite accusative devrés appears in (26a) vs. (26b) and (26c). The clitic doubling in the latter two examples is quasi-obligatory if the direct object is definite (Janse 1998: 538ff.). Note also the use of the definite article in (26b), where to devrés is a definite direct object, versus its absence in (26c), where devrésis is a definite subject.

The same texts provide some more examples. In the first scene, the boy stays with a café-keeper to be his servant (Dawkins 1916: 412):
a. státen séna kaifedžís ${ }^{16}$
stand.AOR.PASs.3sg to.a café.keeper.INDEF.ACC.SG
"he [the boy] stayed with a café-keeper"
b. státen so kaifedži
stand.AOR.PASS.3sg to.the café.keeper.DEF.ACC.SG
"he [the boy] stayed with the café-keeper"

The difference between the indefinite accusative kaifedžis (27a) and the definite accusative kaifedži (27b) recurs in a subsequent scene in which a Jew wants to kill the boy (Dawkins 1916: 412):
a. pijen séna kasápis ${ }^{17}$
go.AOR.3sg to.a butcher.INDEF.ACC.SG
"he [the Jew] went to a butcher"
b. paréngilen to kasáp
order.AOR.3sG the butcher.DEF.ACC.SG
"he gave the butcher an order"
c. pijen séna kababdžís
go.AOR.3sG to.a roast.meat.seller.INDEF.ACC.SG
"he [the Jew] went to a roast-meat seller"
d. paréygilen to kababdží
order.AOR.3SG the roast.meat.seller.DEF.ACC.SG
"he gave the roast-meat seller an order"

The same text also provides an example of the $s$-less nominative with a possessive suffix attached in combination with an indefinite accusative (Dawkins 1916: 412):
(29) a. péӨanen vašiljó-mas die.AOR.3sg king.NOM.SG-1PL "our king is dead"
b. na píkume $e^{18} \quad$ éna vašiljós
PRT make.AOR.SUBJ.1PL a king.INDEF.ACC.SG
"we will make a [new] king"


A pair very similar to those in (28) comes from a folktale from Gúrzono (Southwest Cappadocian) about a princess and another unfortunate robber (Dawkins 1916: 344):
a. na vajíkis $^{19}$
éna aslánis ${ }^{20}$
PRT leave.AOR.sUBJ.2SG a lion.INDEF.ACC.sG
b. ke kaplánis
and panther.INDEF.ACC.SG
"leave a lion and a panther"

(31) a. édokén doso aslán

give.AOR.3SG it to.the lion.DEF.ACC.SG

b. ke so kaplán

and to.the panther.DEF.ACC.SG

"she gave it [the robber's head] to the lion and the panther"

The next batch comes from a story from Axó about a gypsy who eats the sheep he is supposed to keep and tries to fool the owner with a story about a wolf (Dawkins 1916: 396):
a. áma tranižne $e^{21}$ to liko
kilízunde
when see.PRES.3PL the wolf.DEF.ACC.SG roll.PRES.PASS.3PL "as soon as they see the wolf, they roll over each other"
b. líkos tróx ta wolf.NOM.SG eat.PREs.3SG them.CL "the wolf eats them"
c. tránsan do liko see.AOR.3PL the wolf.DEF.ACC.SG "they saw the wolf"
d. líko éfajén da wolf.DEF.NOM.sG eat.AOR.3sg them.CL "the wolf ate them"

Very noteworthy in this particular set is the absence of clitic doubling in (32a) and (32c) and especially the $s$-less (definite) nominative líko in (32d). An indefinite accusative líkos also features in the following proverb from Axó (Mavrochalyvidis \& Kesisoglou 1960: 180)::22
a. to dé ksevri
na vlákśn $^{23}$
to škilí
REL not know.PRES.3SG PRT bark.AOR.SUBJ.3sG the dog.NOM.SG "the dog that doesn't bark" 

b. fér
sta próvata líkos
bring.PRES.3sG to.the sheep.ACC.PL wolf.INDEF.ACC.SG
"leads a wolf to the sheep"

The following set is taken from a story from Sílata (Northwest Cappadocian) about yet another unfortunate person who got mangled by forty thieves (Dawkins 1916: 448):
a. kótša ${ }^{24}$ éna á⿴ropos
érapsá to
lately a man.INDEF.ACC.SG sew.AOR.3sg him.CL
"lately I sewed up a man"
b. éna áOropos iferén me
a man.NOM.sG bring.AOR.3sg me
éna partšalanmiš ${ }^{25}$ á ropos
a mangled man.INDEF.ACC.sG
"a man brought me a mangled man"

The following set illustrates the occasional reanalysis of $s$ as a suffix marking indefiniteness (cf. 19). It comes from a story from Axó about two brothers (Mavrochalyvidis \& Kesisoglou 1960: 196). Note the use of ekí as a noun modifier in (35b) and (35c) and of course the definite nominative to mílo in (35c):
a. ívren éna issïiz mílos
find.AOR.3sg a deserted mill.INDEF.ACC.SG
"he found a deserted mill"
b. sémen ${ }^{27}$ ekí sto mílo
enter.AOR.3sg that in.the mill.DEF.ACC.SG
"he went inside that mill"
c. ekí to mílo djavoljú jatá $x^{28}$ ton
that the mill.DEF.NOM.SG devil.GEN base be.IPF.3sG.CL
"that mill was a devil's haunt"

Indefinite accusatives occur frequently in predicative complements. The following examples are from Araván (Southwest Cappadocian, Phosteris \& Kesisoglou 1960: 116), Mistí (Central Cappadocian, Dawkins 1916: 384), and Anakú (Northwest Cappadocian, Costakis 1964: 36) respectively:
a. na me pí
pséftis
PRT me call.AOR.SUBJ.3SG liar.INDEF.ACC.SG
"she will call me a liar" 

b. ksévalén du pištikós
put.out.AOR.3sg him shepherd.INDEF.ACC.SG
he sent him out as a shepherd"
c. píken do átropos
make.AOR.3SG him man.INDEF.ACC.SG
"he made him a man"

The next example is from Sílata (Dawkins 1916: 452) and contains two indefinite accusatives of which the first is remarkable, as it is a rare example of a feminine noun with indefinite $s$ attached:
(37)
a. éna forás
éna vašiléyas
one time.INDEF.ACC.SG one king.NOM.SG
b. píken so apáno pólemos
make.AOR.3sg to.the above war.INDEF.ACC.SG "one time a king made war upon the above [king]"

The following examples all contain indefinite nouns or noun phrases denoting time. The first one is from Anakú (Costakis 1964: 44):
a. tésera xrónus
stá $\theta a$
éna
four year.NOM/ACC.PL stand.AOR.PASs.1sG one "one time I stayed four years"
b. éna xrónos stá $\theta a$ álo
one year.INDEF.ACC.SG stand.AOR.PASS.1sG another "another time I stayed one year"

The next examples form a minimal pair illustrating the optionality of the phenomenon. The first is from Potámja (Northeast Cappadocian, Dawkins 1916: 605 ) and has the ancient masculine accusative singular; the second is from Flojitá (Northwest Cappadocian, Dawkins 1916: 605) and has the indefinite neuter-inanimate accusative singular:
a. énay geró
one time
"one time"
b. éna kerós
one time
"one time"

I conclude with some examples from a Farasiot Cyclops-story (Dawkins 1916: 550). Note the attachment of indefinite $s$ in xorios (40b) and (40d), the indefinite accusative babás (40e) which is formally identical with the nominative babás in (40a) and (40c), and the use of the definite article in o tepekózis (40f): ${ }^{29}$ 


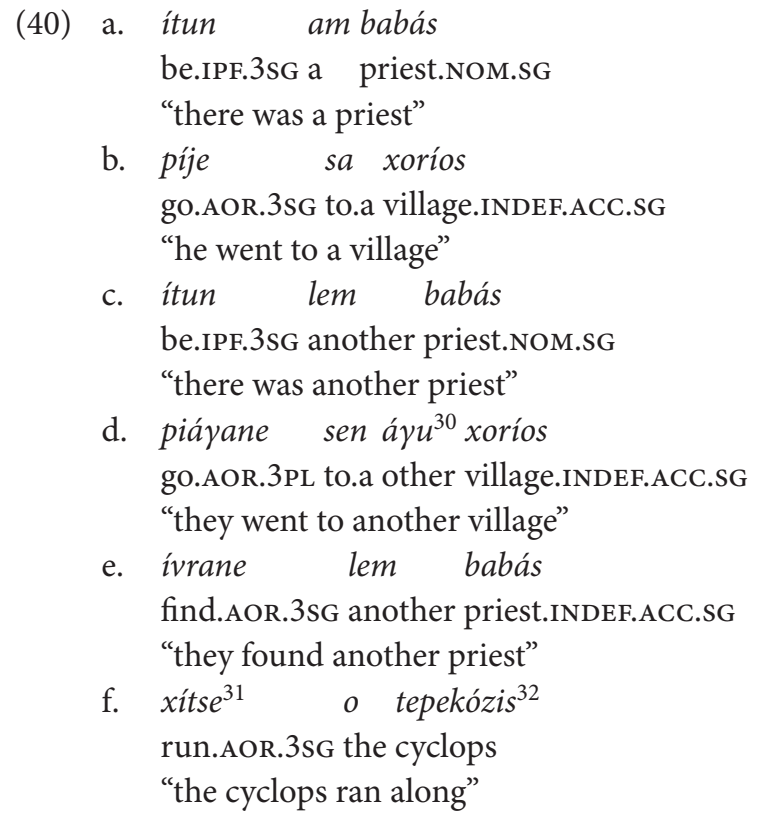

\section{Conclusion}

In this article I have discussed a number of morphological features that uniquely distinguish Cappadocian from the other Greek dialects and add it to the list of languages with differential object marking. The development of an agglutinative declension of the type átropoz-ja-ju and of an indefinite accusative formally identical with the nominative of the type átropos is due to Turkish interference and a typical example of contact-induced change in the sense of Thomason \& Kaufman (1988). The Cappadocian agglutinative declension is quite unique among the Greek dialects, whereas the indefinite accusative is paralleled only in Farasiot and challenged only by the Pontic definite nominative. The animacy split observed in Cappadocian nouns in -os is equally exceptional, though this development cannot be traced back to Turkish interference. ${ }^{33}$ Noteworthy is the fact that the features of definiteness and animacy maximally apply to the masculine noun classes only, even though animacy plays a crucial role in the assignment of Turkish nouns to the various Cappadocian noun classes. This article therefore contributes not only to Greek dialectology, but also to linguistic typology and contact linguistics. 


\section{Notes}

* This research was supported in part by grants from the Fund for Scientific Research-Flanders (1.5.116.00 \& 1.5.172.03) and the Netherlands Organisation for Scientific Research (365-50-011). Earlier versions of this article were presented at the 6th International Conference on Greek Linguistics in Rethymno (September 2003), as part of seminars taught at the Universities of Patras (May 2004) and Thessaloniki (June 2004), and embryonically as part of a series of invited lectures on a Farasiot Cyclops-story at the Universities of Amsterdam (June 2001), Crete (October 2001), Thessaloniki (February 2002), and Patras (April 2002), the Amsterdam Center for Language and Communication (June 2002), and The Ohio State University (January 2004). I gratefully acknowledge the comments from the various audiences and their good mood.

1. For early statements of more extended animacy hierarchies, see Silverstein (1976: 122), Comrie (1978: 384ff.), and Dixon (1979: 85).

2. Abbreviations: $\mathrm{ABS}=$ absolutive, $\mathrm{ACC}=$ accusative, $\mathrm{CL}=$ clitic, $\mathrm{DEF}=$ definite, $\mathrm{GEN}=$ genitive, $\mathrm{INDEF}=$ indefinite, $\mathrm{NOM}=$ nominative, $\mathrm{PL}=$ plural $(1 \mathrm{PL}$ etc. $), \mathrm{PRES}=$ present, $\mathrm{SG}=$ singular (1sG etc.).

3. It should be noted that there is no strong correlation between definiteness and the word order in Greek (Lascaratou 1994: 143f.).

4. On the classification of Cappadocian subdialects and the relationship between Cappadocian and other Asia Minor Greek dialects, especially Farasiot and Pontic, see Dawkins (1916: 204ff.) and Janse (2004: \$1.4).

5. Unstressed /i/ and / $\mathrm{u} /$ are regularly deleted in word-final position (Dawkins 1916: 62, Janse 2004: \$2.4.1.1.1).

6. On Cappadocian geminates, see Janse (2004: \$2.2.4).

7. Animate and especially human nouns in - $\mathrm{C}$ with hypocoristic meaning are integrated in this class as well, e.g. arkadaş "friend" > arkadáś, kardaş "brother" > kardáš.

8. Note the transcription of Turkish sounds in Cappadocian: $\imath=\ddot{i}, \ddot{o}=\ddot{o}, u=\ddot{u}, c=d \check{z}, c ̧=t \check{s}$, $\breve{g}=\gamma, h=x, s=\check{s}, y=j$.

9. On the change from / $\theta /$ to /ç/, see Mavrochalyvidis \& Kesisoglou (1960: 19).

10. For early statements on the relationship between syncretism and markedness, see Hjelmslev (1935) and Jakobson (1936).

11. Note the position of stress in átropoz-ju, átropoz-ja, and especially átropoz-ja-ju (Janse 2004: 22.5 .1$)$

12. Turkish kuyu "well".

13. Note the homophony of definite bašá-s in (23e) with indefinite bašá-s in (23a). 
14. It should be noted that the (definite?) nominative-accusative is meló < mialó (Mavrochalyvidis \& Kesisoglou 1960: 8).

15. Turkish derviş from Persian darvǐš "poor, religious mendicant”.

16. Turkish kahveci "coffee-house owner".

17. Turkish kasap "butcher", kebapçı "seller of roast meats" (28c).

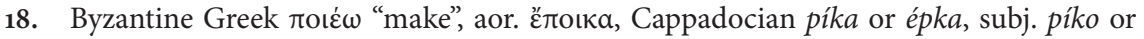

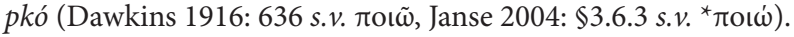

19. From afíno > vaíno "leave" (Dawkins 1916: 587 s.v. ả $\varphi \eta \dot{v} v \omega$, Janse 2004:\$\$2.4.2.7, 3.6.3 s.v. $\alpha \varphi \eta \dot{v} v \omega)$.

20. Turkish aslan "lion", kaplan "tiger, panther" (b).

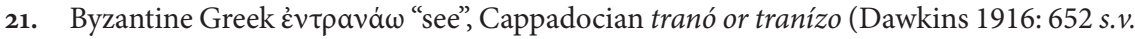

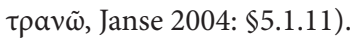

22. On Cappadocian relatives, see Janse (1999).

23. From vlázo "bark" (Mavrochalyvidis \& Kesisoglou 1960: 97 s.v. $\beta \lambda a ́ \zeta \omega)$.

24. Turkish geç "late".

25. Turkish parçalanmış, participle of parçlanmak "break up, disintegrate".

26. Turkish $\imath s s i z$ "lonely, desolate".

27. Byzantine Greek $\mu \beta a i v \omega$ "enter", Cappadocian méno, aor. sém(b)a or ém(b)a (Dawkins 1916: 598 s.v. $\mu \beta a i v \omega$, Janse 2004: $\$ 3.6 .3$ s.v. $\mu a i v \omega)$.

28. Turkish yatak "bed; den; base".

29. From énan > an (am, ay, a) (Dawkins 1916: 163), álo éna > len (lem, ley, le) (Dawkins 1916: 583 s.v. ö $\lambda \lambda$ oc), séna > sen, sa(n) (definite so).

3o. From áu < álu (Dawkins 1916: 149, 158, 583 s.v. å $\lambda \lambda$ oc).

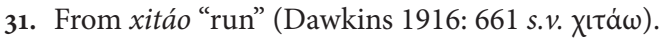

32. Turkish tepegöz "cyclops", as in the Cyclops-story in the Çepni dialect of Trabzon province recorded by Brendemoen (2002: 258f.). Tepegöz is part of the Oghuz oral tradition as recorded in the late-medieval epic of Dede Korkut (Lewis 1974). The word tepegöz is from tepe "crown of the head" and göz "eye" (pace Mundy 1956: 286ff.). The Oghuz cyclops is actually depicted as having his eye on the crown of the head instead of on the forehead (Dawkins 1955: 14). For Pontic versions of the Cyclops-story, see Dawkins (1955: 19ff.). In Pontic,

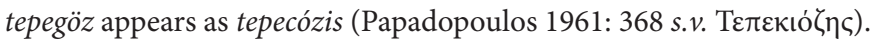

33. Dawkins notes that an animacy split is observable "to a less degree at Phárasa, and very markedly in Pontic" (1916: 90; see also n. 1), though I find the evidence less compelling (cf. Tombaïdis 1980). 


\section{References}

Aissen, Judith. 2003. "Differential Object Marking: Iconicity vs. economy". Natural Language and Linguistic Theory 21.435-483.

Anastasiadi-Symeonidi, Anna, Angeliki Ralli \& Despina Chila-Markopoulou, eds. 2003. To

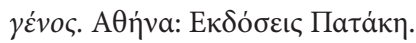

Bossong, Georg. 1985. Empirische Universalienforschung: Differentielle Objektmarkierung in den neuiranischen Sprachen. Tübingen: Gunter Narr Verlag.

Brendemoen, Brent. 2002. The Turkish Dialects of Trabzon: Their phonology and historical development. Vol. II: Texts. Wiesbaden: Harrassowitz.

Comrie, Bernard. 1978. "Ergativity". Syntactic Typology: Studies in the phenomenology of language ed. by Winfred P. Lehmann, 329-394. Austin: University of Texas Press.

Comrie, Bernard. 1987. "Russian". The World's Major Languages ed. by Bernard Comrie, 329-347. London: Croom Helm.

Comrie, Bernard. 1989. Language Universals and Linguistic Typology. 2nd edn. Oxford: Blackwell.

Costakis, Athanase P. 1964. Le parler grec d'Anakou. Athènes: Centre d'Études d' Asie Mineure.

Croft, William. 2003. Typology and Universals. 2nd edn. Cambridge: Cambridge University Press.

Dawkins, Richard MacGillivray. 1916. Modern Greek in Asia Minor: A study of the dialects of Silli, Cappadocia and Phárasa with grammar, texts, translations and glossary. Cambridge: Cambridge University Press.

Dawkins, Richard MacGillivray. 1955. More Greek Folktales. Oxford: Clarendon Press.

Dixon, R. M. W. 1979. “Ergativity”. Language 55.59-138.

Drettas, Georges. 1997. Aspects pontiques. Paris: Association de Recherches Pluridisciplinaires.

Hjelmslev, Louis. 1935. La catégorie des cas: Études de grammaire générale. Aarhus: Universitetsforlaget.

Holton, David, Peter Mackridge \& Irene Philippaki-Warburton. 1997. Greek: A comprehensive grammar of the modern language. London: Routledge.

Jakobson, Roman. 1936. "Beitrag zur allgemeinen Kasuslehre: Gesamtbedeutungen der russischen Kasus". Travaux du Cercle Linguistique de Prague 6.240-299. [Reprinted as: "Contribution to the General Theory of Case: General meanings of the Russian cases". Russian and Slavic Grammar: Studies 1931-1981 by Roman Jakobson, ed. by Linda R. Waugh \& Morris Halle, 59-103. Berlin: Mouton. 1984.]

Janse, Mark. 1998. "Grammaticalization and Typological Change: The clitic cline in Inner Asia Minor Greek". Productivity and Creativity: Studies in general and descriptive linguistics in honor of E. M. Uhlenbeck ed. by Mark Janse, 521-547. Berlin: Mouton de Gruyter.

Janse, Mark. 1999. “Greek, Turkish, and Cappadocian Relatives Revis(it)ed”. Greek Linguistics '97: Proceedings of the 3rd International Conference on Greek Linguistics ed. by Amalia Mozer, 453-462. Athens: Ellinika Grammata.

Janse, Mark. 2002. “Aspects of Pontic Grammar”. Journal of Greek Linguistics 3.203-231. 


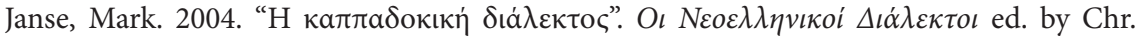

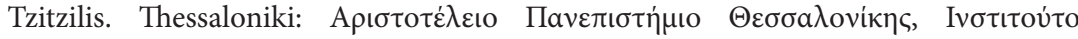

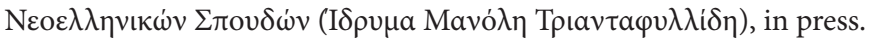

Kornfilt, Jaklin. 1997. Turkish. London: Routledge.

Lascaratou, Chryssoula. 1994. Performance Principles in Word Order Variation. Athens: University of Athens.

Lewis, Geoffrey. 1974. The Book of Dede Korkut. Harmondsworth: Penguin.

Lewis, Geoffrey. 2000. Turkish Grammar. 2nd edn. Oxford: Oxford University Press.

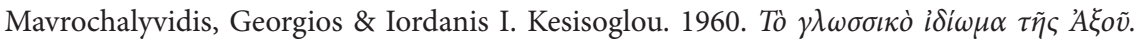

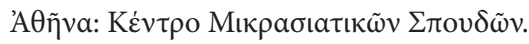

Mundy, C. S. 1956. "Polyphemus and Tepegöz". Bulletin of the School of Oriental and African Studies 18.279-302.

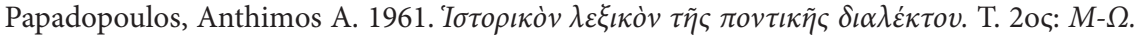

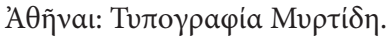

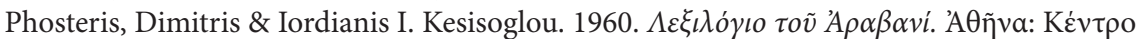

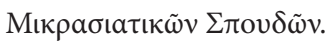

Sasse, Hans-Jürgen. 1992. "Language Decay and Contact-Induced Change: Similarities and differences". Language Death ed. by Matthias Brenzinger, 59-80. Berlin: Mouton de Gruyter.

Silverstein, Michael. 1976. "Hierarchy of Features and Ergativity". Grammatical Categories in Australian Languages ed. by R. M. W. Dixon, 112-171. Canberra: Australian Institute of Aboriginal Studies.

Thomason, Sarah Grey \& Terrence Kaufman. 1988. Language Contact, Creolization, and Genetic Linguistics. Berkeley: University of California Press.

Thumb, Albert. 1910. Handbuch der neugriechischen Volkssprache: Grammatik, Texte, Glossar. 2nd edn. Strassburg: Trübner.

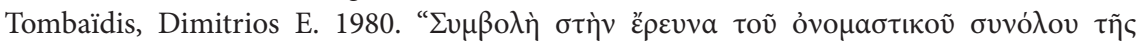

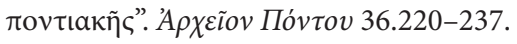

Waugh, Linda R. \& Barbara A. Lafford. 1994. "Markedness". The Encyclopedia of Language and Linguistics ed. by R. E. Asher \& J. M. Y. Simpson, 2378-2383. Oxford: Pergamon Press.

\section{Appendix: Definiteness and 'differential subject marking' in Pontic}

Pontic, a dialect closely related to Cappadocian, has the peculiarity of differential subject marking (Drettas 1997: 120, Janse 2002: 218f.): definite subjects take the accusative case as in the following examples:
a. o túrkon
pánta túrkos
en
the Turk.DEF.NOM.sG always Turk.INDEF.NOM.sg be.3sG.CL
"a Turk will always be a Turk"
b. o palalón ipen
the fool.DEF.NOM.SG say.AOR.3sG
"the fool said" 


\section{palalós $\quad k^{h}$ - ime \\ fool.INDEF.NOM.SG not be.1sG \\ "I am not a fool"}

Dawkins (1916: 94) discusses the same phenomenon, but notes that examples of 'differential subject marking' such as (39) are already attested in the Hellenistic Koine, i.e. before the period of Turkish influence. In other words, it is unlikely that there is any direct relation between differential object marking in Cappadocian and differential subject marking in Pontic.

\section{$\Pi \varepsilon \rho i \lambda \eta \psi \eta$}

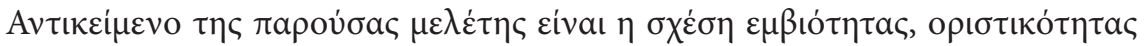

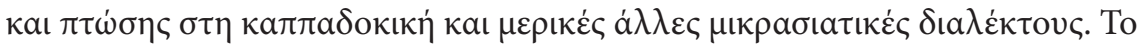

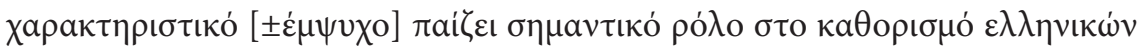

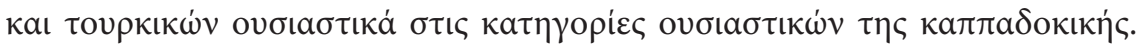

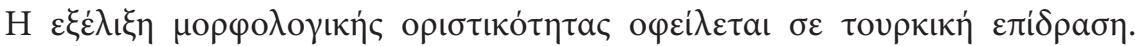

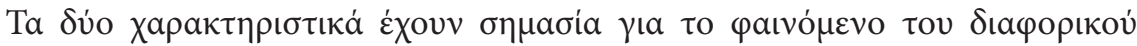

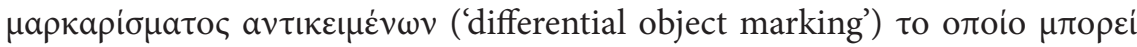

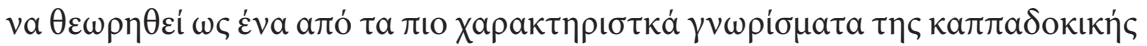

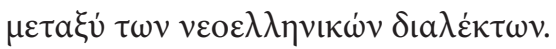

